\title{
Border Control and Using Analysis Tools due to the Humanitarian Aspect of the Immigrant Crisis
}

\author{
Timurlenk Chekovicha, ${ }^{\mathrm{a}}$, Jugoslav Achkoski ${ }^{\mathrm{b}}$ \\ Military Academy "General MihailoApostolski“- Skopje, University "GoceDelcev" - Stip, Skopje, \\ Republic of Macedonia \\ atimurlenk.cekovic@gmail.com, bjugoslav.ackoski@ugd.edu.mk
}

Keywords: migrant, border police, humanitarian crisis

\begin{abstract}
The control of migrants in Europe has become increasingly challenging, marked by a number of illegal border-crossing. It revealed a crisis without equivalent since World War II. The European borders are now one of the most affected by migrants from Asia and Africa. Border police is the most responsible for the first interview with the asylum seeker. In terms of basic contribution to the asylum procedure, good cooperation between the border police and the services of asylum is of primary importance. There is a need of risk assessment. While the risk assessment is made there can be a violation of the humanitarian aspect of conducting regular border check. By determining the race and color of migrants, screening made on the border crossing can put legality of the border police actions in question. The Humanitarian efforts with border management, cooperation between the government services and use of appropriate methodology are an important segment handling migrant crisis. One of the known methodologies is Analysis of Competitive Hypotheses used to better assess the choice of a suitable place for migrants and their acceptance or readmission. The procedure for vulnerable categories of citizens can jeopardize the legality and the manner of dealing with illegal migrants and this arises from the legal and physical protection of persons seeking asylum. The 'politics of pity' changes into psychological cases to be governed by risk technologies within a 'politics of risk', the humanitarian and security interventions are shown to be in no way mutually exclusive.
\end{abstract}

\section{Introduction}

There is no universally accepted definition of illegal migration. Avoiding necessary authorization and document required for immigration regulation usually leads to irregular migration. There is also an irregularity when a person crosses an international border without a valid travel document in case of necessity or to avoid war. Using illegal border crossings and illegal ways to cross international border is called illegal migration. The term 'illegal migrants' has been criticized in migration studies and apart from the problem with alternative terms in some cases it is suitable to use this form of expression for someone who has a change in legal regulations and is connected to processes of differentiation and exclusion [1]. There is a scientific approach from Paspalanova [2] that suggests the use of "illegal migrant/ alien" should be seriously reconsidered and replaced with alternative terms, such as "undocumented" or "irregular immigrant," which are both terminologically correct and lack the negative social implications of the phrase "illegal immigrant/alien". International Organization for migration (IOM) defines a migrant as any person who is moving or has moved across an international border or within a State away from his/her habitual place of residence, regardless of the person's legal status [3]. The term 'illegal' to describe an asylum seeker, refugee or migrant should not be used. Judicially and ethically, an act can be legal or illegal but a person cannot. Moreover, entering a country in an irregular fashion, or staying with an irregular status, should not be considered a criminal activity but an infraction of administrative regulations. But can there be illegal human beings?! Officially, yes.

More than a million migrants crossed the EU border in 2015/16 and sparked a crisis in Europe, making difficulties to cope with this influx of people. The year 2019 will be the crucial year for the future of the EU and the Balkan region (Macedonia, Serbia, Bulgaria, and Greece) because most of 
the European countries closed the borders for the irregular migrants and only temporarily opens the borders for the irregular migrants and refugees. There are different number of estimates and while the International Organization for Migration (IOM) put the figure to more than 1,046,600 migrants arrived by sea and land, the EU's external border force (Frontex) put the figures crossing into Europe in 2015 at more than $1,800,000$. [4]

Border Management in the countries of European Union usually includes coordination and collaboration between relevant departments and agencies involved in border security and trade facilitation to establish effective and efficient border management systems. In this term, the tendencies are to achieve the common goal of open, but 'controlled' and 'safe' borders. One of the main issues to reach necessary standard is setting up Integrated Border Management (IBM) and control of 'illegal' migrants. Border security management focuses on operation (resources, forecast, recruitment and training), regulatory frameworks (strategy, legislation and regional cooperation), operations (traveler processing, modalities of entry and residence, inquiry and procedures for vulnerable migrants like refugees, trafficking persons and trafficked persons), and Information Management systems (data management, alert lists and passport and visa systems). [5] IBM has a particular problem with regulation and status of asylum seekers procedures for individuals who use our country as a transit zone and commit 'illegal' crossing or decide to stay. Most often, 'illegal' passers-by come from Greece and after completing their obligations and illegal work on plantations in Greece, they are directed to other European countries. In most cases, they use Macedonia and neighboring countries (Bulgaria and Albania) to arrive at the 'promised' destination easier. However, many of them end up without funds or receive different information about the destination country, after which they stay in Macedonia or return to Greece.

It is necessary to collect data at the national level, to exchange information, and the arising problem is being encountered. These kinds of complications need to be resolved in timely manner and with effective application of human rights. Migrants and people entering a certain country are not only a national dilemma, but also a wider worry that affects EU and Balkan states. Therefore, it is necessary to stress this matter, to offer solutions and suggestions.

At the entrance, the police officers should distinguish between asylum seekers and 'illegal' migrants, between immediate humanitarian need and basic human rights. Authority figure must differentiate between the most endangered people, like older and disabled, women and children, and men who find it easier to settle with varying difficulties.

\section{Related Work and Methodology}

There are different approaches and analytical methodologies which enable analysts to organize a structure and accomplish their analysis tasks like Delphi technique, probability diagrams and techniques, inductive method, formulaic approach, etc. There is also scenario planning analysis that is strategic tool showing an outcome and the effect of a particular issue [44]. The issues of migrant are explained by Jill Williams in From humanitarian exceptionalism to contingent care: Care and enforcement at the humanitarian border, and also William Walters in his book The deportation regime: Sovereignty, space, and the freedom of movement, which are very important for this subject. When we talk about critical historical events and security-related theories, we must see the context in which they appeared in order to know how to apply them. All these transformations have appeared in certain periods of the past in social and political theory.

Such literature pointed to the possibility and structure of political issues in the normative political steps that weare seeing to day with 'open but controlled and safe borders' in Europe. Recent human security studies has tended to project human security as either a general label for assessing non-military threats or as a descriptive itinerary of challenges to individuals' quality of life [6]. The security requirements of the international community are being increasingly linked to the internal behavior of its individual member-states. If international security is to be achieved, it must address the behavioral challenges that are emerging. The human security model offers a way to respond to these challenges - upholding the contemporary international order without devaluing its most important function: safeguarding and improving the quality of life of those individuals and groups 
that constitute the state's reasons for being [7]. So, there is a need of a systematic approach of solving the arising issues and implementing social, economic and political reforms which will correct the underlying insufficiency.

The research method in this paper is a continuation of the Structured ACH in which the practical problems are faced by analysts on the spot. Instead of taking into account some complex aspects of security, the issues are simplified and applied from a common open source program, so the analysts can produce a chart that can be used as a reference model. Some of the methods and issues used in this paper are introduced in papers like Evaluation of a Computer Support Tool for Analysis of Competing Hypotheses [8] - a continuation of Extending Heuer's Analysis of Competing Hypotheses; Method to Support Complex Decision Analysis [9] - a formal approach that is known as an Analysis of Competing Hypotheses using Subjective Logic, better known as ACH-SL which development was made by Simon Pope and Audun Josang. [10]

It is similar to the emergence of hypothesis mapping (HM) (Carswell, 1988.). HM is an extension of argument mapping to handle abductive reasoning, i.e. reasoning involving selection of the best explanatory hypothesis with regard to a range of available or potential evidence. Hypothesis mapping is also a software-supported method for laying out complex hypothesis sets and marshalling the evidence and arguments in relation to these hypotheses.

Analysis of Competing Hypotheses [11] (ACH) is a technique, applied for a large amount of data for evaluation. Our task is to develop a matrix of hypotheses for already collected information and put it into the table. The data must be reassembled, but the initial phases of the ACH process may require additional time. Developing the matrix will give other policymakers a review of analysis and they can identify the areas of agreement and disagreement.

\section{Migration and Security Policy}

Migration is increasingly interpreted as a security problem [12]. Humanity is facing a global explosion of population from around 6.5 billion people up to 8 billion until 2025 [13]. A UN projection of population worldwide calculates doubling of the population in Africa from 900 million (with $42 \%$ less than 15 years old) up to 2 billion until 2050. The population in the most populated countries of Asia registered a plus of $286 \%$ growth from 1950 to 2004 . Further increase of $78 \%$ is estimated until 2050. Five African countries - Morocco, Algeria, Tunisia, Libya and Egypt has estimated population of 165 million, and prognoses forecast its increase up to 195 million by 2020 [14]. One in every 122 people in the world is now either a refugee, displaced or seeking asylum. This is an increase of over a third in the last five years. According to the United Nations High Commissioner for Refugees (UNHCR, or The UN Refugee Agency), there are 59.5 million displaced people across the world, of which 19.5 million are refugees. The rising number of migrants in recent times has resulted from wars that are occurring in African and Asian countries. Apart from such migration due to political and military reasons, the biggest migration is still due to economic reasons. Republic of Macedonia is trying to stop the influx, but the outbreak of asylum seekers from our country, has not been exempted from it. Asylum encompasses a variety of elements, including nonrefoulment, permission to remain on the territory of the asylum country, respect for human rights and eventually a long-term solution. An asylum-seeker is an individual who is seeking international protection. An asylum-seeker is someone whose claim has not yet been finally decided on by the country in which he or she has submitted it. Not every asylum-seeker will ultimately be recognized as a refugee.

Immigration control in some cases can impose increasingly harsh condition and suffering on migrants, including refugees. This is undermining a long list of human rights: not to be subjected to inhuman treatment, not to be degraded, not to be tortured, arrested and imprisoned the right of a fair trial, the right of a family life and connection, the right to work and earn money and so on [15]. Border police, customs, veterinary or sanitary inspection and other auxiliary services, play a significant role in improving and facilitating border management. Border control must ensure the safety and health of people, animals, plants and cultural heritage. That is why the respect, protection and promotion of the rights of refugees, including respect for the principle of non-refoulment; admission to safety; 
access to fair procedures for the determination of refugee status; the implementation of durable solutions. Given that potential threats are many, a quick and simultaneous effective control system is necessary, so the management is essential to be integrated and applied. The increased international trade and tourism, and the increase of cultural and educational exchanges, leads to the need of better facilitation of legal movement of people and goods, which is significant strategic goal of most countries. Border services must balance between strict controls related to risk analysis and open borders and uninterrupted flow of people and goods. There are various causes of displaced persons, forcible and international [16]. The displacement may be caused by a number of factors, the most common being armed conflict. Natural disasters, famine, development and economic changes may also be a cause of displacement.

\section{The Schengen Area and Cooperation}

Visa policy of the Republic of Macedonia is the same as the visa policy of the Schengen area. It grants a 90-day visa-free entry permit to all Schengen Annex II nationalities [17]. Schengen area is a territory where the free movement of persons is guaranteed. The signatory states of the Schengen treaty have abolished internal borders instead of a single external border. Regarding visas for short stays, asylum requests and border controls, common rules and procedures are applied. To guarantee security within the Schengen area, cooperation and coordination between police services and judicial authorities have been intensified. Schengen cooperation has been incorporated into the European Union (EU) legal framework by the 1997 Treaty of Amsterdam. However, all countries cooperating in Schengen are not part to the Schengen area. This is because they do not wish to end border controls, or because they do not yet fulfill the required conditions for the application of the Schengen acquis (legal acts).Border control between the members countries are maintained until the EU Council decides the conditions for abolishing internal border controls is realized [18]. Article 5 of the Schengen Borders Code (SBC) defines the common prerequisites for third country nationals to cross EU borders for temporary stays in the Schengen area. Each individual who would like to cross the EU borders requires a valid travel document (a National passport) and a valid visa or resident permit. $\mathrm{He} / \mathrm{she}$ must prove travel reasons, sufficient financial funds to pay daily expenses and may not have a notice or refusal of entry in the Schengen Information System (SIS). The person who has obtained Schengen visa may not be considered a threat to public policy, internal security, public health or the international relations of the member states. Each individual who has a resident permit or visa for a longer stay in any Schengen member state has a transit right, even if not all conditions are fulfilled (Art. 5, para 4 SBC) [19].

\section{Border Security and Immigration Control}

An access control point is a place where the information or objects are entering for his checkup [20]. It should have the ability to make decisions on its own, which may lead to some security issues. So it's protected from outside and situated in the open, but a protected area.

Modern border management needs to balance these two goals - i.e. border security and continuous movement of people and goods. It should be done in an effective and efficient way, adequate equipment (developed technical aids and facilities) and well-trained and motivated staff. Managing the border is important as legal foundation, setting division of tasks and responsibilities, harmonizing processes and efficient exchange of information. Taking into account the complexity of the task, this cooperation and coordination should not be limited only on one ministry or service, but should exist between those involved in domestic border management and internationally. Services need to understand they have common aspiration and tasks, that their individual goals can be achieved only through communication and joint effort.

A 'secure state' untroubled by contested territorial boundaries could still be inhabited by insecure people [21]. International security politics must widen its focus and include not only 'the security of borders' but ... 'the security of people's lives' [22]. 
According to the CARDS (Community Assistance for Reconstruction Development and Stabilization) program [23], one of the important meanings is to keep the boundaries open for trade and movement of people and goods. Borders should also be open to regional cooperation, to be an initial impetus and a basis for future integration and membership in the European Union. Borders should be open between the region (for example, the Western Balkans) and the EU. Facilitating regular border crossings improves the economic exchange and development of the entire region. Free trade and movement of people are key elements of the Stabilization and Association Agreements. Borders should be an obstacle to crime and other forms of illegal smuggling, to alert for certain activities of jeopardizing stability in the country and the region. [24]

Border constraints help prevent crime growth, to prevent criminal activities and to reduce the crime rate. The fight against crime makes durable justice and establishes the rule of law. This predicament is fundamental to the progress of West Balkan countries towards European integration. A relevant warning sign due to illegal migration is organized crimes that increase other forms of instability, including terrorism and extreme nationalism. But does this pose another question of illegality and migrant suitability? Another key concern here is to formulate more precisely the theoretical status of migrant "illegality" and deportability in order that further research related to undocumented migration may be conceptualized more rigorously. [25]

The establishment of the National Coordination Center (NCC) for Border Management gives a high coordination between the institutions that have competencies in the Integrated Border Management System. Basic mission of NCC is realization of the joint plans and procedures for dealing with emergencies. This has established an organized and coordinated measures of the bodies involved in the IBM. It is supervising the legality of the arrival and departure of individuals, goods and means of transport, prevention and detection of organized crime, prevention of perpetrators of criminal offenses and various types of smuggling through border crossings, controlling and preventing illegal transfer of substances and contagious diseases that endanger people and goods. IBM supports the country in strengthening the operational capability of border crossing checks and in enhancing concerted border management cooperation of various stakeholders (inter-institutional, inter-institutional and international). [26]

\section{Human Rights Issues}

The fundamentals of human rights [27] - the respect for each individual human life and dignity - are found in major world religions and philosophies. Human rights should not be bought, earned or inherited - they are called "inalienable" because no one has the right to take away any right for any reason. Everyone has the undisputed sovereignty over their own basic rights. This means they are inherent in every human being, regardless of race, color, sex, language, religion, political or other opinion, national or social origin, property, status after birth or other status. Human rights are important in the relations between people and the state. They control and regulate the exercise of state power over individuals, hence individual freedom is guaranteed by the state, and individual rights are required to satisfy the basic needs of people under its jurisdiction. These individual rights are best described in the international texts agreed upon by European states, setting standards in human rights. One such document is the European Convention on human rights, [28] - which protects the fundamental human rights, expressed through protocols that have a strong influence in the entire legal and political world. Refugees are also holders of fundamental rights, and hence have access to the basic rights established in the Convention Relating to the Status of Refugees of 1951 and its 1967 Protocol, as well as to the human rights enshrined by other international instruments, both universal and regional. [29]

The war in Syria is one of the worst disasters in this century. Over 400,000 people have been killed [30] and more than a million injured. Millions of people, including women, children, handicapped and elderly people, have been evicted, tortured, raped, kidnapped, robbed, hungered, and faced with shortage of essential medical aid and medicines. The level of conflict in Syria has testified an unprecedented intensity of warfare and destruction of entire settlements and cities like 
Aleppo, chemical attack on Ghouta, Damascus. The war in Syria, which spilled over to Iraq in 2014, many inquired into the violations of the laws of armed conflict and human rights - crimes which have tested the moral qualms of the world.

European Convention on human rights was adopted in 1950 [31] within the Council of Europe, an international organization formed after the World War II, following the first postwar attempt to unite Europe and the need to elaborate the obligations arising from council membership [32]. In a more general sense, the Convention was a response to past and present developments in Europe, which in the first place arose from the desire and the need to protect the European states from the growth of communism after the World War II. The European Convention on human rights is a symbolic statement of the principles pursued by liberal European states, and a tool that could play a major role in the protection of the communist subversion. It was a reaction to the serious human rights violations that Europe faced during World War II. Expectations were that the European Convention on human rights would warn the other Western European countries in the event of massive human rights violations and allow timely action to prevent them, but this role remained marginal. The primary use of the European Convention on human rights was to raise issues of specific human rights violations in countries that respect its demands. European Convention on Human Rights has become a charter of rights while the European Court of Human Rights assumes a part that has similarities with the constitutional court in national legal systems. The Dublin Convention and Dublin Regulation[33] is an important document regarding the EU asylum policy that establishes the principle in which only one member state examines an asylum application - the first EU country reached by the asylum seeker.

\section{Challenges at the National Levels - Case Study}

The Republic of Macedonia still lacks a comprehensive political document for its integration policy for immigrants. Keeping this in mind, it would not be an effective development of an isolated strategy to integrate refugees and foreigners in the society, with no reflection on the wider context of migration and cultural implications in the integration processes. Republic of Macedonia, as well most European countries, is exposed to growing migration within the processes of globalization. It is a multicultural state and in its policy must reflect an additional element, integration of the newcomers in a society, composed of different ethnic groups, emphasizing their cultural differences.

The issues related to refugees and foreigners with long-term residence in the country should be approached within the broader concept of state policy, directed at social issues, in relation with changing the demographic situation. With the amendments to the Law on Asylum (the Law on asylum and temporary Protection) [34] dated 07.17.2015, a foreigner at the border crossing or inland may appear in front of a police officer. Then, he/she can proclaim his intention to submit an application for recognition of the right for asylum. Within 72 hours he/she can apply for recognition of the right to asylum in front of an authorized official of the Asylum Department in the premises of the Reception Center for asylum seekers [35]. If the asylum seeker submits a new request for recognition of the right to an asylum, he/she must provide evidence that his/her circumstances have altered since the moment of adoption of the former decision to reject his/her request to recognize the asylum right [36]. If he/she fails to do so, the Asylum Department shall reject the request. Border police has a special authority in returning and readmission of illegal immigrants and foreigners. The rejected asylum seekers are deported and escorted by the border police officers. Good cooperation between agencies and services is a basic and comprehensive approach for better human rights protection. Under the applicable legal framework in Republic of Macedonia, asylum-seekers may enjoy freedom of movement and protection of arbitrary arrest or detention [37]. Coordination of the agencies is also of great importance to prevent illegal migration. By enacting bylaws, the template of the stated intention for submitting a request to recognize the asylum right is the application to recognize the right of asylum. Also, the manner of fingerprinting and photographing the asylum seekers has been crucial for this operation. By adopting these decisions, the Border police authority point that the problem of illegal migration from one side will be solved, and it will facilitate the potential asylum seeker access to the body that administers the procedure to recognize the asylum right. 
It should be noted, the distinction between trafficking and migrant smuggling is not always easy to determine and manage in practice. The border police should follow the criminal procedure Code, where migrants and asylum-seekers can be arrested together with their smugglers and considered being witnesses in the criminal cases pursued against the latter [38]. For example, many trafficked persons, men, and women begin their journey as smuggling migrants - concluding an agreement with an individual or with a group to assist in illegal movement as a returning financial benefit. In the classical situation of smuggling migrants, the relationship between the migrant and the smuggler are voluntary, short-term and ends after the migrant arrive in the country of destination. However, some smuggled migrants are forced to continue this relationship to pay the heavy transport costs. It is in this late phase the goal is apparent (debt bond, extortion, use of force, forced labor, forced crime, forced prostitution) [39]. Border police officers and other agencies, should recognize the early signs of forced relationship between migrants. Giving the right information about suspicious behavior can lead in detection of inhuman treatment and blackmail.

There is a need to avoid or minimize any adverse effects and reduce risks, in particular the risk of exposing people to increased danger or abuse of their rights. All agencies need to ensure that people in need can access all necessary services and humanitarian help accord to the need only and without adverse discrimination, with attention to their vulnerabilities and respect of their rights. Amnesty international repeated their concerns about the conditions, and the detention of children, pregnant women and breastfeeding mothers in Macedonian detention centers [40]. As evidence, concerns have been expressed by the Macedonian Ombudsperson, the designated National Preventive Mechanism (NPM). Recommendations by UNHCR in Macedonia are that refugee status determination (RSD) interviews should be conducted by civilians, but till now Asylum Office staff conducting such interviews are Ministry of Interior police officers.

Basic human rights should be taken into account in assessing and selecting a checkpoint. The right to health care, the right to legal aid and counseling, the right for police protection, the right for freedom of access to public transport and other rights are perceived in the model which needs to be developed. It is also important to include those elements that raise concerns about security of the citizens, and the measures and procedures that need to be taken for better security of the state.

\section{Analysis of Competing Hypotheses for Setting a Suitable Control Point}

a. Scenario objective- results

One of the border management services is to provide the refugees with the items they need to ensure dignity and protection. There is a need to ensure access to items that will reduce the risks of exposure to different weather and well-being of the people in need. The fundamental purpose of all security activities is to enhance the physical and psychological security, or at least reduce insecurity of target population, to reduce the risk and extent of harm by minimizing threats of violence, coercion, or intentional deprivation and by reducing their vulnerability to such threats, strengthening the selfprotection capacities and enhancing the opportunities to ensure safety and dignity.

Our aim is to establish control access point for refugees and illegal migrants. The selected area will provide us a good example of how this technique can be applied. This model suggests that after an initial flurry of illegal border crossing, military and border police were called in to help and organize regular border checks. The assumptions are that security checks should be imposed in one of the three proposed locations. Our goal is to choose the best solution from the hypotheses in progress. Humanitarian aspect of migrants and the needs of the local population should be considered. It is assumed that among the migrants there will be people who are sick and in dare need, but maybe there is a risk of those who have taken part in the battlefields of Syria or Iraq.

All of these risks factors should be put in consideration. 


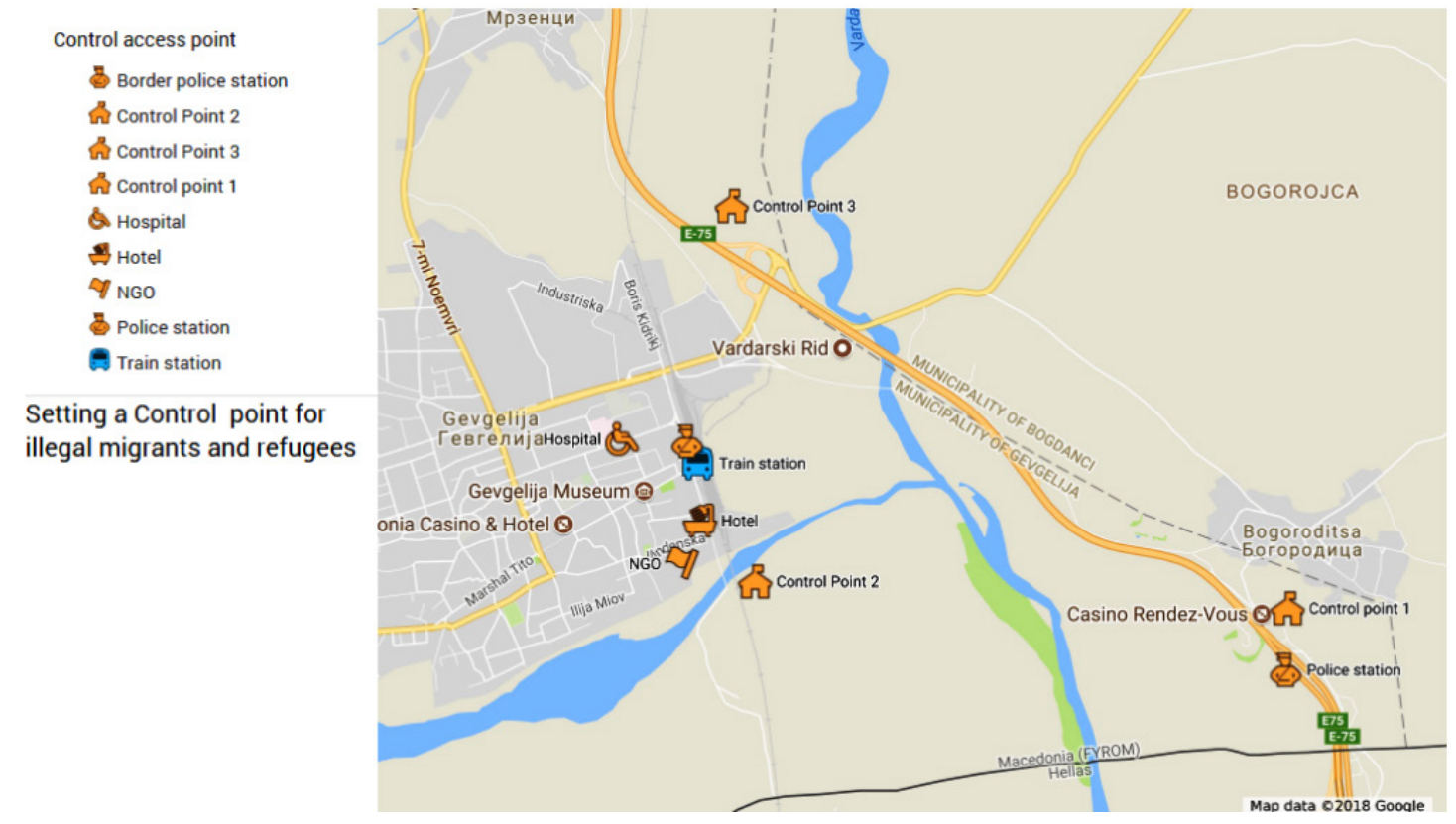

Figure 1. Setting a Control point for illegal migrants; CP1, CP2 and CP3 represent the control points suggested for the model. Map data C OpenStreetMap contributors, CC-BY-SA

\section{b. Model objective}

The integral parts of ACH are evidence and hypotheses. These parts are related to each other by analyzing the consistency or inconsistency of each item of evidence with each hypothesis. The analysis is presented in the form of a matrix in which the analyst enters information about these parts and their relationship with each other. Using chart we can set a matrix for setting a control access point near Gevgelija. The difficult part of the matrix is that when the evidence changes, we include more parameters leading to complex problem-solving tables. We avoid this by simplifying the hypotheses. Using the precise indicators, perceiving and selecting appropriate locations, gives a model that can be studied with the proposed method. The tables are an example of how can border police/ security guard make informal assessment with the elements he meet on the ground.

Table 1. Analysis of setting the Control access point (CP1, CP2, CP3) which show us the seriousness and the indicators of the concerns we have to consider for government capacity

\begin{tabular}{|l|l|l|l|l|}
\hline Topic & Indicators & CP1 & CP2 & CP3 \\
\hline \multirow{4}{*}{$\begin{array}{l}\text { Government } \\
\text { capacity }\end{array}$} & Organizational capabilities & Low concern & $\begin{array}{l}\text { Low } \\
\text { concern }\end{array}$ & $\begin{array}{l}\text { Moderate } \\
\text { concern }\end{array}$ \\
\cline { 2 - 5 } & $\begin{array}{l}\text { Ability to deliver basic goods } \\
\text { and services }\end{array}$ & Low concern & $\begin{array}{l}\text { Low } \\
\text { concern }\end{array}$ & Low concern \\
\cline { 2 - 5 } & Security capabilities & Low concern & $\begin{array}{l}\text { Low } \\
\text { concern }\end{array}$ & $\begin{array}{l}\text { Moderate } \\
\text { concern }\end{array}$ \\
\cline { 2 - 5 } & Human rights violations & $\begin{array}{l}\text { Moderate } \\
\text { concern }\end{array}$ & $\begin{array}{l}\text { Serious } \\
\text { concern }\end{array}$ & $\begin{array}{l}\text { Moderate } \\
\text { concern }\end{array}$ \\
\hline
\end{tabular}


Table 2. Analysis of setting the Control access point (CP1, CP2, CP3) which show us the seriousness and the indicators of the concerns we have to consider for non-government capacity

\begin{tabular}{|l|l|l|l|l|}
\hline Topic & Indicators & CP1 & CP2 & CP3 \\
\hline \multirow{5}{*}{$\begin{array}{l}\text { Non-government } \\
\text { capacity }\end{array}$} & Organizational capabilities & Low concern & $\begin{array}{l}\text { Moderate } \\
\text { concern }\end{array}$ & $\begin{array}{l}\text { Low } \\
\text { concern }\end{array}$ \\
\cline { 2 - 5 } & $\begin{array}{l}\text { Ability to deliver basic goods } \\
\text { and services }\end{array}$ & $\begin{array}{l}\text { Moderate } \\
\text { concern }\end{array}$ & Low concern & $\begin{array}{l}\text { Low } \\
\text { concern }\end{array}$ \\
\cline { 2 - 5 } & Political participation & Low concern & $\begin{array}{l}\text { Moderate } \\
\text { concern }\end{array}$ & $\begin{array}{l}\text { Low } \\
\text { concern }\end{array}$ \\
\cline { 2 - 5 } & $\begin{array}{l}\text { Religious groups } \\
\text { intimidation }\end{array}$ & Low concern & $\begin{array}{l}\text { Moderate } \\
\text { concern }\end{array}$ & $\begin{array}{l}\text { Low } \\
\text { concern }\end{array}$ \\
\hline
\end{tabular}

Table 3. Analysis of setting the Control access point (CP1, CP2, CP3) which show us the seriousness and the indicators of the concerns we have to consider for immigrant activity

\begin{tabular}{|l|l|l|l|l|}
\hline Topic & Indicator & CP1 & CP2 & CP3 \\
\hline \multirow{5}{*}{$\begin{array}{l}\text { Immigrant } \\
\text { activity }\end{array}$} & Organizational capabilities & Low concern & Low concern & $\begin{array}{l}\text { Low } \\
\text { concern }\end{array}$ \\
\cline { 2 - 5 } & Transnational criminal & $\begin{array}{l}\text { Moderate } \\
\text { concern }\end{array}$ & Low concern & $\begin{array}{l}\text { Low } \\
\text { concern }\end{array}$ \\
\cline { 2 - 5 } & Strikes and riots & $\begin{array}{l}\text { Serious } \\
\text { concern }\end{array}$ & $\begin{array}{l}\text { Serious } \\
\text { concern }\end{array}$ & $\begin{array}{l}\text { Low } \\
\text { concern }\end{array}$ \\
\cline { 2 - 5 } & $\begin{array}{l}\text { Transport (Railway, Buses, } \\
\text { Car) access }\end{array}$ & $\begin{array}{l}\text { Moderate } \\
\text { concern }\end{array}$ & Low concern & $\begin{array}{l}\text { Low } \\
\text { concern }\end{array}$ \\
\cline { 2 - 5 } & $\begin{array}{l}\text { Threat of conflict with local } \\
\text { community }\end{array}$ & Low concern & $\begin{array}{l}\text { Serious } \\
\text { concern }\end{array}$ & $\begin{array}{l}\text { Low } \\
\text { concern }\end{array}$ \\
\cline { 2 - 5 } & Terrorist group activity & Low concern & Low concern & $\begin{array}{l}\text { Low } \\
\text { concern }\end{array}$ \\
\hline
\end{tabular}

Table 4. Analysis of setting the Control access point (CP1, CP2, CP3) which show us the seriousness and the indicators of the concerns we have to consider for environmental issues

\begin{tabular}{|c|c|c|c|c|}
\hline Topic & Indicator & $\mathrm{CP} 1$ & $\mathrm{CP} 2$ & $\mathrm{CP} 3$ \\
\hline \multirow{3}{*}{$\begin{array}{l}\text { Environmental } \\
\text { issues }\end{array}$} & $\begin{array}{l}\text { Food and energy } \\
\text { shortages }\end{array}$ & $\begin{array}{l}\text { Low } \\
\text { concern }\end{array}$ & Low concern & $\begin{array}{l}\text { Moderate } \\
\text { concern }\end{array}$ \\
\hline & $\begin{array}{l}\text { Ability to respond to } \\
\text { natural disasters }\end{array}$ & $\begin{array}{l}\text { Low } \\
\text { concern }\end{array}$ & Low concern & $\begin{array}{l}\text { Moderate } \\
\text { concern }\end{array}$ \\
\hline & $\begin{array}{l}\text { Extent of environmental } \\
\text { degradation }\end{array}$ & $\begin{array}{l}\text { Low } \\
\text { concern }\end{array}$ & $\begin{array}{l}\text { Moderate } \\
\text { concern }\end{array}$ & Low concern \\
\hline
\end{tabular}

\section{c. Model using PARC ACH 2.0.5}

We can also use free software PARC ACH 2.0.5. (ACH software version 2.0.5 2010) for risk assessment. ACH software is one useful tool for focusing attention on discrepant evidence and alternative explanations [41]. It is impossible to represent dependencies among items of evidence that are present even when the hypotheses are known. Such dependencies would be modeled by introducing intermediate variables between hypotheses and items of evidence. We note that this is a serious issue when trying to model rumors and deception. It is impossible to model context for hypotheses [42] so we use the direct issues concerning migrants. Attributing the values for the consistency reduced the time for checking our best hypothesis. 
ACH software version 2.0.5 can be used in completing the matrix with values, after which we can use them for consistency check. With refuting the hypotheses the analysts are seeking how to refute and not to accept the hypotheses. So we have to acknowledge the point which has the least of "bad" evidence against the place which is the result of our findings. In absence of evidence, one's belief in a hypothesis cannot affect the belief in another hypothesis.

\begin{tabular}{|c|c|c|c|c|c|c|c|}
\hline \multirow{4}{*}{ 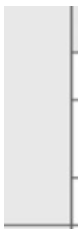 } & (1) & Type & Credibility & Relevance & $\mathrm{H}: 1$ & $\mathrm{H}: 2$ & $\mathrm{H}: 3$ \\
\hline & & & & & cp1 & cp2 & cp3 \\
\hline & $\begin{array}{l}\text { Weighted Inconsistency } \\
\text { Score } \Rightarrow\end{array}$ & & & & -4.0 & -7.0 & -2.0 \\
\hline & Enter Evidence & & & & & & \\
\hline E8 & $\mathrm{CP}$ location is safe for clinic & & MEDIUM & MEDIUM & 11 & 11 & 1 \\
\hline E7 & $\begin{array}{l}\mathrm{CP} \text { is near the railway } \\
\text { station }\end{array}$ & & MEDIUM & MEDIUM & 1 & c c & c c \\
\hline E6 & $\begin{array}{l}\mathrm{CP} \text { is away from residential } \\
\text { area }\end{array}$ & & MEDIUM & MEDIUM & c & 1 & C C \\
\hline E5 & $\mathrm{CP}$ has access to roads & & MEDIUM & MEDIUM & $\mathrm{C} \mathrm{C}$ & 1 & $\mathrm{C} \mathrm{C}$ \\
\hline E4 & $\begin{array}{l}\mathrm{CP} \text { is located to serve } \\
\text { significant immigration } \\
\text { population }\end{array}$ & & MEDIUM & MEDIUM & 1 & 11 & 1 \\
\hline E3 & $\begin{array}{l}\mathrm{CP} \text { in proximity of police } \\
\text { station }\end{array}$ & & MEDIUM & MEDIUM & c c & C & c \\
\hline E2 & $\begin{array}{l}\mathrm{CP} \text { is in area of existing } \\
\text { accomodation facility }\end{array}$ & & MEDIUM & MEDIUM & $\mathrm{N}$ & 1 & $\mathrm{~N}$ \\
\hline E1 & $\begin{array}{l}\mathrm{CP} \text { is in area of presence } \\
\text { illigall migrant }\end{array}$ & & MEDIUM & MEDIUM & C C & c & C C \\
\hline
\end{tabular}

Figure 2. Screenshot of results simulated by software PARC ACH 2.0.5

The evidence shown in the upper table is Consistent (C) with the hypothesis, Inconsistent (I), very Consistent (CC), or very inconsistent (II). The evidence in the table can be shown as Neutral (N). From the model and the values which we used for the analysis the software confirmed that there is least negative result in hypothesis 3 (CP3). In our case, hypothesis 3 has the most consistent evidence for setting a control point.

Getting the right conclusion depends on objectivity and detailed information that provides a more reliable result for the choice of the set model. By using these methodologies the security guard avoid making assessment which is made out of prejudice or some kind of behavior of the illegal migrants. Throughout the world, increasingly securitized and militarized border enforcement efforts have made transnational migration an increasingly deadly endeavor for unauthorized migrants.

\section{Conclusion}

Meeting the basic needs of those people to preserve their dignity and enable them a better quality of life is the basic moral and civilization norm of the European Union. There is a need for risk assessment before the procedure goes on. The deadly consequences of unauthorized migration have compelled the emergence of what William Walters refers to as the humanitarian border-the concentration of humanitarian aid and services along the edges of the global North. [43] Article 33(2) (Convention Relating to the Status of Refugees, 1951) discusses about forced return of refugees whenever a reasonable ground exists. These grounds can be based on biases like the Security of the State. This is very subjective logic and anything can be added under the spectrum of security of the State. That is why states are using it as a defense to discard their obligation towards refugees.

The fundamental purpose of all security activities is to enhance the physical and psychological security, or at least reduce insecurity of target population, to reduce the risk and extent of harm by minimizing threats of violence, coercion, or intentional deprivation and by reducing their vulnerability to such threats, strengthening the self-protection capacities and enhancing the opportunities to ensure safety and dignity. 
In this paper we introduce new directions for intelligence analysis. The basic claims about the $\mathrm{ACH}$ method is that it promotes a fuller set of alternative hypotheses. They receive a more equitable distribution of attention focused on evidence with the greatest diagnostic value, reducing the confirmation bias. ACH seeks the key evidence. Separating different components and using detailed analysis with PARC ACH software, we made proposals and suggestions for the future risks and events and delivered the final project. Finding the right location is crucial for fulfilling the humanitarian need and aspects of the migrant crisis.

The analyst who applies the ACH methods to migrants in a migrant/refugee crisis faces a number of security challenges. He presents the key assumptions and look for sources of danger that must be included in the hypotheses. These hypotheses should give the answer whether they will apply some additional screening measures or increase humanitarian aspects of the analytical judgment. By using these methodologies, the analysts avoid making assessment which is made out of prejudice or some kind of behavior of the illegal migrants. Securitization has recently played an enormous role and its reduction depends on the speed at which an analyst has to make decisions and directly influences the process of migrant screening, thereby avoiding the main security risks. The results are logical, methodical and may give better risk assessment. The humanitarian aspects are fulfilled and the security measures will not violate the condition of people in difficult circumstances.

The standard for safe admission and control of immigrants are met by reducing the risk of humanitarian needs and giving help to people, requiring medical care and decent conditions. Their needs are fulfilled and the security measures will not violate the humanitarian character of people in difficult circumstances.

\section{Conflict of Interest}

The authors declare that there is no conflict of interest.

\begin{tabular}{|c|c|}
\hline & ABBREVIATIONS \\
\hline ACH & Analysis of Competing Hypotheses \\
\hline $\mathbf{E U}$ & European Union \\
\hline IBM & Integrated Border Management \\
\hline NPM & National Preventive Mechanism \\
\hline RSD & Refugee status determination \\
\hline SBC & Schengen Borders Code \\
\hline SIS & Schengen Information System \\
\hline UNHCR & United Nations High Commissioner for Refugees \\
\hline
\end{tabular}

\section{References}

[1] M. Schrover (Ed.), Illegal migration and gender in a global and historical perspective, Amsterdam University Press, 2008.

[2] M. Paspalanova, Undocumented vs. illegal migrant: Towards terminological coherence, Migraciones internacionales. 4(3) (2008) 79-90.

[3] IOM. 2011, Glossary on Migration, International Migration Law Series.

[4] Frontex.europa.eu. (2016). Frontex. Risk analysis. [Online]. Available: http://frontex.europa.eu/intelligence/risk-analysis/. 
[5] International Organization for Migration, Migration and Border Management Assessments, International Organization for Migration. 9 Feb. 2015. Web. 25 Jan. 2018. Available: https://www.iom.int/migration-and-border-management-assessments.

[6] R. Paris, Human Security: Paradigm Shift or Hot Air?, International Security. 26(2) (2001). 87102.

[7] N. Thomas, W.T. Tow, The utility of human security: sovereignty and humanitarian intervention, Security Dialogue. 33(2) (2002) 177-192.

[8] P. Pirolli et al., Evaluation of a computer support tool for analysis of competing hypotheses, Palo Alto, CA: Palo Alto Research Center (UIR Technical Report), 2004.

[9] M. Valtorta et al., Extending Heuer's analysis of competing hypotheses method to support complex decision analysis, 2005. Available at http://www. cse. sc. edu/ mgv/reports/IA-05. pdf.

[10] S. Pope, A. Josang, Analysis of competing hypotheses using subjective logic, Queensland Univ Brisbane (Australia), 2005.

[11] R.J. Heuer Jr, Psychology of Intelligence Analysis. Washington, DC: Central Intelligence Agency, Center for the Study of Intelligence, 1999.

[12] Security and Immigration: Toward a Critique of the Governmentality of Unease. 2002 Didier Bigo Vol 27, Issue 1_suppl, pp. 63 - 92. https://doi.org/10.1177/03043754020270S105

[13] United Nations, Department of Economic and Social Affairs, 2013. Probabilistic Population Projections based on the World Population Projects: The 2012 Revision.

[14] W. Karioth, Detlef. Border Management Issues: Border Security and Humanitarian Aspects. 10 Dec. 2014. Web. 25 Jan. 2018.

[15] T. Hayter, Open borders: The case against immigration controls, London: Pluto Press, 2000.

[16] R. Cohen, The guiding principles on internal displacement: An innovation in international standard setting, Global Governance. 10(4) (2004) 459-480.

[17] "Ministry of Foreign Affairs". www.mfa.gov.mk.". Retrieved 25 January, 2018.

[18] W. Walters, Mapping Schengenland: denaturalizing the border, Environment and Planning D: Society and Space. 20(5) (2002) 561-580.

[19] Guide on article 5 - Right to liberty and security. Council of Europe/European Court of Human

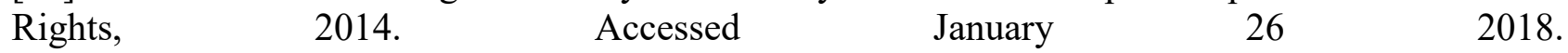
http://www.echr.coe.int/Documents/Guide_Art_5_ENG.pdf.

[20] K. Nohl, H. Plötz, Establishing Security Best Practices in Access Control, 2009.

[21] C. Böck, „Ostbanden“ im „Sicherfühlland“ Der politischeDiskurs um Kriminalität ,ausOsteuropa“, 2017. Institute for Advanced Studies (IHS). Available: http://irihs.ihs.ac.at/2192/1/rs 105.pdf.

[22] N. Thomas, W.T. Tow, The utility of human security: sovereignty and humanitarian intervention, Security Dialogue. 33(2) (2002) 177-192.

[23] Support to participation of South-Eastern European countries in the stabilization and association process ("Closed programme").

[24] House, Freedom. Freedom in the world 2014: The annual survey of political rights and civil liberties. Rowman\& Littlefield, 2014.

[25] N.P. De Genova, Migrant "illegality" and deportability in everyday life, Annual Review of Anthropology. 31(1) (2002) 419-447. 
[26] International Organization for Migration. "Integrated Border Management." International Organization for Migration. 9 Feb. 2015. Web. 25 Jan. 2018. https://www.iom.int/integrated-bordermanagement

[27] Universal Declaration of Human Rights, Un.org. 6 Oct. 2015. Web. 25 Jan. 2018. Available: http://www.un.org/en/universal-declaration-human-rights/.

[28] Council of Europe. European Court of Human Rights. 14 Feb. 2017. Web. 25 Jan. 2018. Available: http://www.echr.coe.int/Documents/Convention_ENG.pdf.

[29] D. Phulwary, Refugee Rights Vis-A-Vis Security Of State: Striking A Balance.

[30] J. Garriaud-Maylam, Committee On The Civil Dimension Of Security, 2017. Available: www.nato-pa.int.

[31] Article 1, The 1951 Convention related to the status of refugees and its 1967 Protocol, published by UNHCR, September 2011, p.3 available at http:/www.unhcr.org/pages/49da0e466.html

[32] Van Dijk et al., Theory and practice of the European Convention on Human Rights. Martinus Nijhoff Publishers, 1998.

[33] Council Regulation (EC), No 343/2003, 18 February 2003.

[34] Law on Asylum and Temporary Protection, published in the Official Gazette No. 54 on 15 April 2013. Available: http://www.slvesnik.com.mk/Issues/3dfflee8f23e4547ad198661fe794149.pdf. Accessed: 28.01.2018.

[35] O. Kosevaliska, B. Tusevska, A.N. Krstevska, Migration crisis: Macedonia on crossroads, 2015.

[36] Article 33 of the LATP. Available:

http://eprints.ugd.edu.mk/16515/1/Migration\%20crisis.\%20Macedonia\%20at\%20crossroads.pdf.

[37] Article 3 from the Law on Foreigners, published in the Official Gazette of the Republic of Macedonia No. 35 on 25 March 2006.

[38] Criminal Procedure Code, published in the Official gazette No. 150 on 18 November 2010, entered into force on 01.12.2013.

[39] F. Shanty, Criminal Enterprises and Sources of Financing, Organized crime: from trafficking to terrorism, 2007, p. 169.

[40] C. Veigel et al., The 'Gazi Baba' Reception Centre for Foreigners in Macedonia: migrants caught at the crossroad between hypocrisy and complying with the rule of law, The International Journal of Human Rights. 21(2) (2017) 103-119.

[41] Heuer Jr, Richards J., Psychology of Intelligence Analysis. Washington, DC: Central Intelligence Agency, Center for the Study of Intelligence, 1999.

[42] M. Valtorta et al., Extending Heuer's analysis of competing hypotheses method to support complex decision analysis, in: Proceedings of the 2005 international conference on intelligence analysis (IA-05)(CDROM), 2005. Available: http://www. cse. sc. edu/ mgv/reports/IA-05. pdf.

[43] W. Walters, Migration and security. The handbook of new security studies, 2010, pp. 217-228.

[44] S.P. Bradley, A.C. Hax, T.L. Magnanti, Applied mathematical programming, 1977. 